10-2005

\title{
Longitudinal Analysis of Relationships Between Planning and Performance in Small Firms
}

Brian Gibson

Gavin Cassar

University of Pennsylvania

Follow this and additional works at: https://repository.upenn.edu/accounting_papers

Part of the Accounting Commons, and the Entrepreneurial and Small Business Operations Commons

\section{Recommended Citation}

Gibson, B., \& Cassar, G. (2005). Longitudinal Analysis of Relationships Between Planning and Performance in Small Firms. Small Business Economics, 25 (3), 207-222. http://dx.doi.org/10.1007/

s11187-003-6458-4

Dianne Wingham was a co-author for this article prior to its publication in the Small Business Economics journal. The authors of the final version are Brian Gibson and Gavin Cassar. (This final version version is available online at: http://link.springer.com/article/10.1007\%2Fs11187-003-6458-4.

This paper is posted at ScholarlyCommons. https://repository.upenn.edu/accounting_papers/74

For more information, please contact repository@pobox.upenn.edu. 


\title{
Longitudinal Analysis of Relationships Between Planning and Performance in Small Firms
}

\author{
Abstract \\ This paper investigates causal relationships between planning and performance utilizing a longitudinal \\ database with responses from the same 2,956 businesses over a four-year period. Results confirm the \\ association between planning activity and performance that is evident in most extant literature. They also, \\ however, cast doubt on the traditional perception of the causal sequence of that association. Although \\ subject to a number of limitations, the results indicate that planning is more likely to be introduced into a \\ small firm after a period of growth rather than before a period of growth. These results make an important \\ contribution to understanding the planning performance relationship for two main reasons: they \\ overcome the static data and relatively smaller sample size restrictions of many past studies; and, they \\ provide evidence concerning the sequence of the relationship between planning and performance.

\section{Keywords} \\ small firm, performance relationship, planning activity, extant literature, four-year period, industrial \\ organization

\section{Disciplines} \\ Accounting | Entrepreneurial and Small Business Operations

\section{Comments} \\ Dianne Wingham was a co-author for this article prior to its publication in the Small Business Economics \\ journal. The authors of the final version are Brian Gibson and Gavin Cassar. (This final version version is \\ available online at: http://link.springer.com/article/10.1007\%2Fs11187-003-6458-4.
}




\title{
LONGITUDINAL ANALYSIS OF RELATIONSHIPS BETWEEN PLANNING AND PERFORMANCE IN SMALL AUSTRALIAN FIRMS
}

Brian Gibson, The University of Newcastle Gavin Cassar, University of California, Berkeley

Dianne Wingham, Edith Cowan University

\begin{abstract}
The analysis in this paper utilises results from a longitudinal database with responses from the same 2,956 businesses over a four-year period. Results confirm the association between planning activity and performance that is evident in most extant literature. They do, however, cast doubt on the traditional perception of the causal direction of that association. Although subject to a number of limitations, the results indicate that planning is more likely to be introduced into a small firm after a period of growth rather than before a period of growth.
\end{abstract}




\section{LONGITUDINAL ANALYSIS OF RELATIONSHIPS BETWEEN PLANNING AND PERFORMANCE IN SMALL AUSTRALIAN FIRMS}

\section{INTRODUCTION}

Much of the mainstream research literature relating to small firms continues to emphasise correlations between "best practice" management activities and performance. Research with this emphasis is presumably driven by a perceived need to establish a set of "desirable" management activities that all small firms should implement. When these activities are passed on to small firm managers through appropriate knowledge dissemination processes there is an expectation of a more efficient and effective small firm sector.

This research project presents the opportunity to test hypotheses about the relationship between one indicator of good management activity (the existence of documented business plans) and performance (as indicated by expansion in employment and growth in sales income). Indicating the difficulty of determining meaningful generalisations from past research, the paper commences with a review of the diversity of attempts to determine operational definitions of the performance construct. This is followed by a review of findings in relation to the management practice of planning. The research questions are then presented before providing a description of the data set used, the analysis employed and the specific variables utilised. After presenting the outcomes of data analysis, the significance of the results is discussed.

\section{ASSESSING PERFORMANCE IN SMALL FIRMS}

While it is the central construct of interest in much research it is unfortunately not always clear what performance means or what are appropriate operational definitions. The diverse nature of the performance construct is reflected in the variety of operational definitions used in recent 
empirical studies. Murphy, Trailer and Hill (1996) provide an analysis of publications for the seven years to 1993 that are classified according to dimensions of performance considered. In 51 articles studied, they found 71 different measures of performance that they group in eight major dimensions of which efficiency, growth and profit are most frequently used (Murphy, Trailer and Hill, 1996, p.16). Similar interpretations and analysis of the performance construct facilitate the three categories discussed below: those that define performance by reference to traditional financial measures with either a static or dynamic perspective; those that rely on non financial operational measures; and, those that seek to develop other, more subjective, effectiveness measures.

The traditional financial measures used to represent performance are themselves diverse although they do appear to be most commonly used. At the most basic level performance has been categorized according to static annual sales (turnover) or income (pre and post income tax) measures (Chandler, 1996; Dyke, Fischer and Reuber, 1992; McMahon and Davies, 1994). The other common categorization using annual financial measures is where returns on sales, assets or equity are incorporated (Appiah-Adu, 1997; Begley and Boyd, 1986; Chrisman and Leslie, 1989; Daily and Dalton, 1992; Hornaday and Wheatley, 1986; Keasey, Short and Watson, 1994). However, not all performance criteria are viewed as static and many studies seek to differentiate firm performance by considering growth in financial attributes such as sales (or revenue or turnover), income or return measures (Appiah-Adu, 1997; Begley and Boyd, 1986; Chandler, 1996; Chrisman and Leslie, 1989; Dyke, Fischer and Reuber, 1992; Hornaday and Wheatley, 1986; McMahon and Davies, 1994; Riggs and Bracker, 1986).

A common non-financial performance measure used is related to the number of employees (usually equated to full time equivalent numbers). These range from absolute numbers (Dyke, Fischer and Reuber, 1992; McMahon and Davies, 1994) to measures incorporating growth in 
employment (Dyke, Fischer and Reuber, 1992; Robson, Gallagher and Daly, 1993) and measures which relate employment to financial measures, such as profit or sales per employee (McMahon and Davies, 1994) or labor expenses as a proportion of revenue (Riggs and Bracker, 1986). While employee related measures are common, a range of other operational but not directly financial measures have also been used. These include new product success (Appiah-Adu, 1997); market share (Chandler, 1996); survival (Robson, Gallagher and Daly, 1993); and, the firm's stage in its life cycle (Dyke, Fischer and Reuber, 1992).

The final categorization is where authors have attempted to assess performance on the basis of more general and subjective criteria. Pelham (1997), for example, attempts to assess performance on the basis of a general measure of effectiveness. Considered are multiple determinants of performance such as product quality, new products success, and customer retention alongside more traditional measures such as sales level, growth rate, target market share, return on equity, gross margin, and return on investment (Pelham, 1997, p.58). O'Neill, Saunders and Hoffman (1987) use a subjective self-assessment criterion. A similar approach is used by Kotey and Meredith (1997) who developed a measure that assesses performance "in terms of variables which generate research and government interest in small firms" (p.48) and included variables such as increased productivity, revenue generation, improved technology, job creation, and community development.

It may be that performance in small firms is best captured by the more subjective criteria that the last group of studies has attempted to incorporate. They would seem to more closely aligned with the determinants of performance identified by Keats and Bracker (1988) and Lumpkin and Dess (1996) in their conceptual frameworks for assessing performance in small firms. However, the need to develop operational definitions that relate to more readily obtained data sources often 
means that performance is measured (as it is in this study) by financial or quantifiable operational activities (such as employment).

\section{PLANNING AND PERFORMANCE IN SMALL FIRMS}

Concern with the study of planning in small firms seems to be of importance for two reasons. Firstly, there is a significant belief that planning, because it is so prevalent in large firms, is a good management practice. Secondly, there is a body of research which finds some association between planning and a variety of performance measures in small firms which is used to enhance the beneficial management outcome of planning.

There is still a dominant belief reflected in business practice research that rational economic behaviour dictates the structured evaluation of alternatives (reflected in traditional planning processes) as the dominant decision making approach in firms of all sizes (Gibson, 1997). Because large organizations which use sophisticated planning systems are seen to be successful, "entrepreneurs are urged to follow suit and install planning systems" (O'Neill, Saunders and Hoffman, 1987, p.38). When smaller firms are observed to "not engage in the type of structured planning reflected in ... normative models" (Shuman and Seeger, 1986. p.8), they are often regarded as exhibiting inappropriate behavior. This is despite evidence and arguments that show small firms are not just "little big firms" (O'Neill, Saunders and Hoffman, 1987) and accordingly "... planning in small enterprises differs from ... planning in larger organizations" (Glen and Weerawardena, 1996). It seems that regardless of these differences there is still a strong intuitive appeal that "has led to a proliferation of academic and practitioner literature stressing the importance of planning, promoting models of the planning process, and offering normative advice on how to effectively design and implement strategic and operational plans" (Lumpkin, Shrader and Hills, 1998). 
Those that study the link between planning and performance in small firms provide further impetus to the importance attached to planning. Rue and Ibrahim (1998) categorize such research into two streams: that which contends planning improves profitability; and, that which recognizes good planning as a key to success (p.24). The underlying planning construct in such studies concentrates on either the content of the plans or the planning process (Rue and Ibrahim, 1998, p.25). The simple existence of written plans has been used to measure the planning process (Berman, Gordon and Sussman, 1997), a view supported by Matthews and Scott (1995) who suggest that the extent to which planning documents exist (formality) has been the most widely used dimension of strategic planning in the literature (p.36).

While some studies show a relationship, few are able to make causal assertions, and there are many studies that simply do not show any relationship (O'Neill, Saunders and Hoffman, 1987). Schwenk and Shrader (1993) used a meta-analysis procedure applied to a range of studies completed before 1990 and found planning to be positively related to several performance measures. Similar associations have been found in recent studies. For example, Olson and Bokor (1995) using 121 firms from fortune 500 companies show that performance is influenced by the interaction of planning formality and innovation (strategy content). Also, Rauch and Frese (1998) found initial support for a positive relationship between planning and success from cross sectional analysis of responses from a survey of 200 German small business owner/managers. Such results are not uniform however with a number of studies questioning the relationship between planning and performance. Both Risseeuw and Masurel (1994) (relying on the results from a survey of 1211 real estate agents in the Netherlands), and Lyles, Baird, Orris and Kuratko (1993) (whose sample consists of 188 Midwestern USA firms) find only weak or moderated relationships. In a follow up survey involving 85 of their initial respondents, Rauch and Frese (1998) could not support their hypothesis that more sophisticated planning leads to more success. No association between planning formality and performance was found by McKiernan and Morris (1994) using 
data from a longitudinal sample of 3000 firms in the UK. Similarly, Lumpkin, Shrader and Hills (1998) found very little correlation between planning and performance in their analysis of 133 firms in Southwestern USA.

As Rue and Ibrahim (1998) comment "evidence regarding the relationship of these [planning] processes with ... performance is mixed" (p.25). Nonetheless normative arguments that planning influences performance continue to find favour. For example, Berman, Gordon and Sussman (1997) on the basis of a correlation between sophisticated planning and growth in revenue conclude "firms that plan produce better financial results than firms that do not plan" (p.4). The extent to which this view prevails, despite the equivocal support, is reflected in a recent recommendation to members of the International Labour Organization which calls for availability and accessibility of support services to include (among 23 categories) "business plan development and follow-up" (ILO, 1998). The outcome of such suggestions is that firms that introduce planning should be rewarded with better performance.

The alternate understanding and explanation for the observed (even if equivocal) result of a relationship between planning and performance is that improved performance might generate conditions where planning becomes more important (Gibson, 1997). Some support for this alternative is evident in the review of past research summarized by Stone and Brush (1996) in which they suggest one of the main determinants of planning in entrepreneurial firms was the "influence of investors or banks for planning document[s]" (p.644). They did not mention a desire for improved performance as a determinant. Stone and Brush (1996) mount a powerful argument to suggest that the planning in entrepreneurial firms is a consequence of internal and external pressures for commitment and legitimacy. 
This paper seeks to improve the body of knowledge in this area in two ways. Firstly, there is an attempt to confirm the relationship between the presence of planning in firms and the achievement of higher performance. Secondly, two alternate explanations for the relationship (that performance precedes planning or that planning precedes performance) are examined.

\section{HYPOTHESES}

The first hypothesis seeks to confirm the expectation reflected in the literature that firms that plan perform better than firms that do not plan. The availability of four consecutive years responses to questions about planning activity enables refinement of the general test of this type of hypothesis by identifying the regular planners and regular non planners which are then able to be compared on up to three years of performance measures.

Hypothesis 1: firms that are regular planners will have better performance compared with firms that are regular non-planners.

The following two hypotheses seek to make an initial exploration of the possible direction of the planning performance relationship. If traditional understanding of the relationship is valid then planning should be introduced prior to improved performance.

Hypothesis 2: firms that become planning introducers will have better performance following the introduction of planning, compared to firms that do not become planning introducers.

If the converse understanding is valid, that the management of more complex activities generates a need to plan, then improved performance should occur before planning is introduced. 
Hypothesis 3: firms that become planning introducers have better performance before the introduction of planning, compared to firms that do not become planning introducers.

\section{THE RESEARCH}

\section{Data}

The analysis in this paper utilises the results from the Business Growth and Performance Survey developed by the Australian Bureau of Statistics (ABS) on behalf of the Office of Small Business (now located in the Australian Federal Government's Department of Workplace Relations and Small Business). The survey collected data for the first time in respect of 1994-95 which was "the first of a planned five year annual series" (ABS, 1998, p.32). However, only four years data was collected. "The surveys were designed to provide estimates on the growth and performance of Australian employing businesses and to identify selected economic and structural characteristics of these businesses" (ABS, 1998, p.32).

For a firm to be included in the analysis reported in this paper it had to meet the following criteria: 1) be an active firm in each year; 2) give responses to all surveys; 3) have less than 200 full-time equivalent employees in 1995; and 4) have positive sales each year. These criteria ensure that only operating firms with reliable data are used in the final sample. The requirement for positive sales eliminates firms that are atypical and ensures that the performance values calculated from sales data are not distorted by unusual values caused by negative signs. After applying the above criteria, a sample size of 2,956 was obtained in each of the years, 1995, 1996, 1997 and 1998.

\section{Variables}

Considering the special character of the data set, the following questionnaire responses have been used as surrogate definitions for the variables analyzed in this paper: 
Employment and Sales Performance is the end of the period employment (sales) minus the beginning period employment (sales) all divided by the beginning period employment (sales).

Regular planners are those respondents who respond yes to the dichotomous question in each year that identifies the presence of a documented formal strategic plan or formal business plan.

Regular non-planners are those respondents who respond no in each year to the questions used in determining regular planners.

Planning introducers are those respondents who at time $t$ responded "yes" to the questions used to determine regular planners, but who at time $t-1$ responded "no".

\section{Analysis}

Given the large number of responses in the database, to test the hypotheses discussed above four statistical tests were performed. The use of different tests ensures that the relationships identified are not influenced by the statistical procedure employed and helps control for the effects of the distributions of the data (Kennedy, Lakonishok and Shaw, 1992; Camp, Nenide, Pricer and Sexton, 1999). Each of the tests applied for both employment and sales measures of performance are described below:

(1) Chi-square: comparing the two planning groups (for the first hypothesis regular and non regular planners and for the other hypotheses planning introducers and non introducers) with firm performance (growth and non-growth). Growth represents a minimum 10\% increase over the time period selected and non-growth represents all remaining firms. 
This $10 \%$ benchmark was chosen following the initial analysis performed by the ABS (ABS, 1997).

(2) T-test: comparing planning groups using performance data Winsorized at 5\%. Winsorization of data reduces the influence of outliers. The T-tests applied did not require the variances of the planning groups to be equal.

(3) Mann-Whitney: comparing planning groups using the raw performance data. This test is non-parametric and is therefore more robust against the distribution of the data. It compares the ranks of the two planning groups with respect to employment and sales growth.

(4) Multiple regression: using performance (employment or sales) as the dependent variable, and size, industry, age and the planning construct as independent variables. The multiple regression attempts to control for the influence of structural characteristics of the firm (size, industry and age), and hence isolate the relationship between planning and performance. Given the assumptions associated with OLS regression, the dependent performance variables are Winsorized at $5 \%$.

\section{RESULTS}

\section{Descriptive Statistics}

The aggregate responses in respect of the planning activity for the four years are summarized in Table 1 . Only $16.3 \%$ of all 2,956 firms are regular planners whereas $43.5 \%$ are regular nonplanners. The remaining $40.2 \%$ (described as irregular planners) has a differing response in at least one year. From the perspective of other questions analyzed in this paper, the proportion of all firms that become planning introducers in 1996 is $13.9 \%, 1997$ is $8.6 \%$ and 1998 is $9.1 \%$. 


\section{Regular Planners Versus Regular Non-planners}

Table 2 provides a summary of the four statistical tests used to analyze the relationship between performance (both employment and sales) of the regular planners compared to the non-planners. Generally the evidence from the Table 3 is consistent with hypothesis 1 that regular planners have better performance than non-planners, with the majority of results being significant at 0.05 . This is especially true for the non-parametric Mann-Whitney $U$ test and the more robust parametric test using multiple regression. This suggests the $2 \times 2$ comparison tested by Chi-square and Ttests may be too restrictive. Even where not highly statistically significant, all results are in the hypothesized direction.

\section{Planning Introduction Before Improved Performance}

Table 3 summarizes performance after planning introduction. The first panel shows the results of comparing 1006-97 performance with firms who were not planning in 1995 and started planning in 1996 (against the firms that didn't start planning in 1996). The results provide no evidence that planning is related to performance. Similarly, comparing 1997 planning introducers with 199798 performance measures provides no evidence to support a hypothesis of association.

Lagged relationships were also tested and are also reported in Table 3. Again none of the tests indicated a significant relationship between planning and performance. A further test for the 1996 planning data was to combine the two years performance for 1996-98. By increasing the time frame of performance the ability to detect an effect between planning and performance could be improved. The results of this analysis are displayed in the last panel of Table 3. There is some evidence of a relationship between planning and future sales performance with the chi-square $(\mathrm{p}=$ .018) indicating a positive relationship. However, the other tests are not significant at conventional levels. Overall the results suggest that there is not a relationship between planning introduction and subsequent performance and therefore hypothesis two cannot be supported. 


\section{Improved Performance Prior to Planning}

The results that test for an alternate relationship based on improved performance occurring prior to planning introduction are presented in table 4. For the 1996 planning introducers compared with 1995-1996 performance data, several of the results are significant at conventional levels. In particular two of the tests (Mann-Whitney and Multiple Regression) involving employment performance are significant at 0.05 (and the T-test result is significant at 0.10 ), providing strong evidence that growth in employment precedes planning introduction. The sales performance results are weaker, with only the Mann-Whitney U test providing strong evidence $(\mathrm{p}<0.05)$ of growth in sales preceding planning introduction.

For planning introducers in 1997 against the preceding year (1996-97) performance measures, again the employment performance relationship is supported with all the results being below $\mathrm{p}=$ 0.051. Again the sales results are weaker with none of the results being significant at the 0.05 level, and the chi-squared result appearing to be in the opposite direction to that hypothesised.

While 1996 and 1997 planning introducers seem to have had improved employment performance prior to becoming planners, in 1998 there is no statistical relationship with either performance measure. However from an overall perspective the employment performance results of the earlier years tend to support hypothesis three that performance (as measured by employment) precedes planning. The financial (sales) performance results in general could only provide weak evidence of a relationship.

\section{DISCUSSION AND CONCLUSION}

The findings of the analysis reported in this paper are significant for several reasons. Firstly, they rely on a large and rigorously collected sample. The use of over 2,900 firms from an ABS data 
set means these results are based on one of Australia's largest and most reliable samples, and accordingly provide a strong basis for generalisation across Australian firms.

The second significance of these results is that they provide support for the general belief that planning is more prevalent in better performing firms. The regular planners are associated with higher levels of performance across all periods analyzed.

Finally, in terms of significant results, there appears to be stronger support for the notion that improved performance precedes planning introduction than for the more popular belief that planning will precede improved performance. Applying the four different statistical methods, there are strong associations when the commencement of planning follows periods of improved (employment) performance. There were at best, limited evidence of associations when performance after the introduction of planning is tested. Consequently these results suggest there may be greater credence to the claim that improved performance is the precursor to planning introduction, rather than the traditional view that planning activity leads to better performance.

This study has several implications for both business policy and practice. A policy implication is that adoption of formal planning by small business need not be an objective of government. Instigating formal business planning to improve the small business sector by encouraging growth may not achieve the desired policy outcome. This does not mean that policy programs providing resources for small businesses to undertake planning should be eliminated, the mere fact that small firms plan and adopt planning suggests positive benefits, however as this study has shown they do not appear to be related to future growth. Wholesale encouragement of formal business planning by the small business sector does not appear warranted. 
A clear implication for business practice is that small business management should not think that it is irrational not to plan. The findings of this study suggest that the use of formal planning does not necessarily result in superior performance. However, it does suggest that businesses that are better performers are more likely to adopt business planning. It is indeterminate from this study whether the adoption of planning by the respondents was related to attempts to cope with increased growth or a legitimization device for future capital requirements, or some other explanation. It is also unclear how useful and what particular benefits were associated with the adoption of a formal business plan. Such questions can be addressed by future research.

Another limitation of the research is an inability to examine the longer-term implications of business planning. Given there are only four data points available the longest lag observed between adoption of planning and performance is one year. Consequently, if formal business planning has a significant positive influence on the growth of the business in later periods, it has not been detected in this study. Data sources that span a longer period and provide increased data points are required if such investigations on longer term performance are to be undertaken. 
Table 1

Firms Planning Status From 1995 To 1998

Planners in :

\begin{tabular}{|c|c|c|c|c|c|c|}
\hline & 1995 & 1996 & 1997 & 1998 & Number & $\%$ \\
\hline $\begin{array}{l}\text { Regular Non- } \\
\text { Planners }\end{array}$ & No & No & No & No & 1287 & 43.5 \\
\hline \multirow{14}{*}{ Irregular Planners } & No & No & No & Yes & 141 & 4.8 \\
\hline & No & No & Yes & No & 70 & 2.4 \\
\hline & No & No & Yes & Yes & 95 & 3.2 \\
\hline & No & Yes & No & No & 130 & 4.4 \\
\hline & No & Yes & No & Yes & 45 & 1.5 \\
\hline & No & Yes & Yes & No & 75 & 2.5 \\
\hline & No & Yes & Yes & Yes & 164 & 5.6 \\
\hline & Yes & No & No & No & 130 & 4.4 \\
\hline & Yes & No & No & Yes & 34 & 1.2 \\
\hline & Yes & No & Yes & No & 33 & 1.1 \\
\hline & Yes & No & Yes & Yes & 56 & 1.9 \\
\hline & Yes & Yes & No & No & 83 & 2.8 \\
\hline & Yes & Yes & No & Yes & 46 & 1.6 \\
\hline & Yes & Yes & Yes & No & 84 & 2.8 \\
\hline Regular Planners & Yes & Yes & Yes & Yes & 483 & 16.3 \\
\hline TOTAL & & & & & 2956 & 100.00 \\
\hline
\end{tabular}


Table 2

Regular Planners Versus Regular Non-Planners and Performance

\begin{tabular}{|c|c|c|c|c|c|c|c|c|}
\hline \multirow[t]{2}{*}{ Performance measure used: } & \multicolumn{2}{|c|}{ Chi-square } & \multicolumn{2}{|c|}{ T-test } & \multicolumn{2}{|c|}{$\begin{array}{c}\text { Mann- } \\
\text { Whitney }\end{array}$} & \multicolumn{2}{|c|}{$\begin{array}{c}\text { Multiple } \\
\text { Regression }\end{array}$} \\
\hline & $x^{2}$ & $\begin{array}{c}p- \\
\text { value }\end{array}$ & $t$ & $\begin{array}{c}p- \\
\text { value }\end{array}$ & $Z$ & $\begin{array}{c}p- \\
\text { value }\end{array}$ & $T$ & $\begin{array}{c}p- \\
\text { value }\end{array}$ \\
\hline \multicolumn{9}{|l|}{ Single year measures: } \\
\hline Employment 1995-96 & 3.089 & 0.079 & .748 & 0.455 & 1.425 & 0.154 & 3.592 & 0.000 \\
\hline Employment 1996-97 & 2.544 & 0.111 & .977 & 0.329 & 2.013 & 0.044 & 2.882 & 0.004 \\
\hline Employment 1997-98 & $(.027)$ & 0.870 & 1.489 & 0.137 & .905 & 0.366 & 2.625 & 0.009 \\
\hline Financial (Sales) 1995-96 & 12.712 & 0.000 & 3.228 & 0.001 & 4.349 & 0.000 & 4.026 & 0.000 \\
\hline Financial (Sales) 1996-97 & .450 & 0.502 & 1.329 & 0.184 & 2.088 & 0.037 & 1.110 & 0.267 \\
\hline Financial (Sales) 1997-98 & .014 & 0.904 & .921 & 0.357 & .842 & 0.400 & .318 & 0.751 \\
\hline \multicolumn{9}{|l|}{ Two year measures: } \\
\hline Employment 1995-97 & 4.781 & 0.029 & 1.231 & 0.219 & 1.470 & 0.142 & 4.365 & 0.000 \\
\hline Employment 1996-98 & 2.436 & 0.119 & 1.832 & 0.067 & 2.154 & 0.031 & 3.993 & 0.000 \\
\hline Financial (Sales) 1995-97 & 18.113 & 0.000 & 3.507 & 0.000 & 4.511 & 0.000 & 4.158 & 0.000 \\
\hline Financial (Sales) 1996-98 & 3.418 & 0.064 & 1.975 & 0.049 & 2.312 & 0.021 & 1.217 & 0.224 \\
\hline \multicolumn{9}{|l|}{ Three year measures: } \\
\hline Employment $1995-98$ & 5.232 & 0.021 & 2.514 & 0.012 & 2.565 & 0.010 & 5.216 & 0.000 \\
\hline Financial (Sales) 1995-98 & 17.701 & 0.000 & 4.142 & 0.000 & 4.893 & 0.000 & 4.403 & 0.000 \\
\hline
\end{tabular}


Table 3

Performance After Planning Introduction

Started Planning in 1996

\begin{tabular}{|c|c|c|c|c|c|c|c|c|}
\hline \multirow[t]{2}{*}{ Performance measure used: } & \multicolumn{2}{|c|}{ Chi-square } & \multicolumn{2}{|c|}{ T-test } & \multicolumn{2}{|c|}{$\begin{array}{c}\text { Mann- } \\
\text { Whitney }\end{array}$} & \multicolumn{2}{|c|}{$\begin{array}{c}\text { Multiple } \\
\text { Regression }\end{array}$} \\
\hline & $X^{2}$ & $\begin{array}{c}p- \\
\text { value }\end{array}$ & $t$ & $\begin{array}{c}p- \\
\text { value }\end{array}$ & $Z$ & $\begin{array}{c}p- \\
\text { value }\end{array}$ & $t$ & $\begin{array}{c}p- \\
\text { value }\end{array}$ \\
\hline Employment 1996-97 & .280 & .597 & 1.237 & .217 & 1.191 & .234 & -.070 & .944 \\
\hline Financial (Sales) 1996-97 & 1.689 & .194 & 1.189 & .235 & 1.419 & .156 & .973 & .331 \\
\hline
\end{tabular}

Started Planning in 1997

\begin{tabular}{|c|c|c|c|c|c|c|c|c|}
\hline \multirow[t]{2}{*}{ Performance measure used: } & \multicolumn{2}{|c|}{ Chi-square } & \multicolumn{2}{|c|}{ T-test } & \multicolumn{2}{|c|}{$\begin{array}{c}\text { Mann- } \\
\text { Whitney }\end{array}$} & \multicolumn{2}{|c|}{$\begin{array}{c}\text { Multiple } \\
\text { Regression }\end{array}$} \\
\hline & & $\begin{array}{c}p- \\
\text { value }\end{array}$ & $t$ & $\begin{array}{c}p- \\
\text { value }\end{array}$ & $Z$ & $\begin{array}{c}p- \\
\text { value }\end{array}$ & $t$ & $\begin{array}{c}p- \\
\text { value }\end{array}$ \\
\hline Employment 1997-98 & .028 & .867 & -.001 & .999 & .074 & .941 & .090 & .928 \\
\hline Financial (Sales) 1997-98 & $(.314)$ & .575 & .237 & .813 & .072 & .942 & .144 & .885 \\
\hline
\end{tabular}

Started Planning in 1996 - lagged one year

\begin{tabular}{|c|c|c|c|c|c|c|c|c|}
\hline \multirow[t]{2}{*}{ Performance measure used: } & \multicolumn{2}{|c|}{ Chi-square } & \multicolumn{2}{|c|}{ T-test } & \multicolumn{2}{|c|}{$\begin{array}{c}\text { Mann- } \\
\text { Whitney }\end{array}$} & \multicolumn{2}{|c|}{$\begin{array}{c}\text { Multiple } \\
\text { Regression }\end{array}$} \\
\hline & $x^{2}$ & $\begin{array}{c}p- \\
\text { value }\end{array}$ & $t$ & $\begin{array}{c}p- \\
\text { value }\end{array}$ & $Z$ & $\begin{array}{c}p- \\
\text { value }\end{array}$ & $t$ & $\begin{array}{c}p- \\
\text { value }\end{array}$ \\
\hline Employment 1997-98 & .067 & .795 & .151 & .880 & .268 & .789 & .706 & .480 \\
\hline Financial (Sales) 1997-98 & 2.032 & .154 & .631 & .526 & .892 & .372 & -015 & .988 \\
\hline
\end{tabular}

Started Planning in 1996 - combined for 1996-1998

\begin{tabular}{|c|c|c|c|c|c|c|c|c|}
\hline \multirow[t]{2}{*}{ Performance measure used: } & \multicolumn{2}{|c|}{ Chi-square } & \multicolumn{2}{|c|}{ T-test } & \multicolumn{2}{|c|}{$\begin{array}{c}\text { Mann- } \\
\text { Whitney }\end{array}$} & \multicolumn{2}{|c|}{$\begin{array}{c}\text { Multiple } \\
\text { Regression }\end{array}$} \\
\hline & $X^{2}$ & $\begin{array}{c}p- \\
\text { value }\end{array}$ & $t$ & $\begin{array}{c}p- \\
\text { value }\end{array}$ & $Z$ & $\begin{array}{c}p- \\
\text { value }\end{array}$ & $t$ & $\begin{array}{c}p- \\
\text { value }\end{array}$ \\
\hline Employment 1996-98 & 1.006 & .316 & -.853 & .394 & .606 & .545 & .233 & .815 \\
\hline Financial (Sales) 1996-98 & 5.589 & .018 & .807 & .420 & 1.546 & .122 & .356 & .722 \\
\hline
\end{tabular}


Table 4

Performance Before Planning Introduction

Started Planning in 1996

\begin{tabular}{|c|c|c|c|c|c|c|c|c|}
\hline \multirow[t]{2}{*}{ Performance measure used: } & \multicolumn{2}{|c|}{ Chi-square } & \multicolumn{2}{|c|}{ T-test } & \multicolumn{2}{|c|}{$\begin{array}{c}\text { Mann- } \\
\text { Whitney }\end{array}$} & \multicolumn{2}{|c|}{$\begin{array}{c}\text { Multiple } \\
\text { Regression }\end{array}$} \\
\hline & $x^{2}$ & $\begin{array}{c}p- \\
\text { value }\end{array}$ & $t$ & $\begin{array}{c}p \text { - } \\
\text { value }\end{array}$ & $Z$ & $\begin{array}{c}p \text { - } \\
\text { value }\end{array}$ & $t$ & $\begin{array}{c}p- \\
\text { value }\end{array}$ \\
\hline Employment 1995-96 & 1.141 & .285 & 1.796 & .073 & 2.284 & .022 & 3.194 & .001 \\
\hline Financial (Sales) 1995-96 & .083 & .773 & 1.660 & .097 & 2.056 & .040 & 1.478 & .140 \\
\hline
\end{tabular}

Started Planning in 1997

\begin{tabular}{|c|c|c|c|c|c|c|c|c|}
\hline \multirow[t]{2}{*}{ Performance measure used: } & \multicolumn{2}{|c|}{ Chi-square } & \multicolumn{2}{|c|}{ T-test } & \multicolumn{2}{|c|}{$\begin{array}{c}\text { Mann- } \\
\text { Whitney }\end{array}$} & \multicolumn{2}{|c|}{$\begin{array}{c}\text { Multiple } \\
\text { Regression } \\
\end{array}$} \\
\hline & & $\begin{array}{c}p- \\
\text { value }\end{array}$ & $t$ & $\begin{array}{c}p- \\
\text { value }\end{array}$ & $Z$ & $\begin{array}{c}p- \\
\text { value }\end{array}$ & $t$ & $\begin{array}{c}p- \\
\text { value }\end{array}$ \\
\hline Employment 1996-97 & 7.134 & .008 & 1.967 & .051 & 2.175 & .030 & 2.545 & .011 \\
\hline Financial (Sales) 1996-97 & $(.077)$ & .782 & 1.017 & .310 & .717 & .473 & .715 & .475 \\
\hline
\end{tabular}

Started Planning in 1998

\begin{tabular}{|c|c|c|c|c|c|c|c|c|}
\hline \multirow[t]{2}{*}{ Performance measure used: } & \multicolumn{2}{|c|}{ Chi-square } & \multicolumn{2}{|c|}{ T-test } & \multicolumn{2}{|c|}{$\begin{array}{c}\text { Mann- } \\
\text { Whitney }\end{array}$} & \multicolumn{2}{|c|}{$\begin{array}{c}\text { Multiple } \\
\text { Regression }\end{array}$} \\
\hline & $X^{2}$ & $\begin{array}{c}p \text { - } \\
\text { value }\end{array}$ & $t$ & $\begin{array}{c}p \text { - } \\
\text { value }\end{array}$ & $Z$ & $\begin{array}{c}p- \\
\text { value }\end{array}$ & $t$ & $\begin{array}{c}p- \\
\text { value }\end{array}$ \\
\hline Employment 1997-98 & .547 & .460 & 1.347 & .180 & .546 & .585 & 1.641 & .101 \\
\hline Financial (Sales) 1997-98 & 2.255 & .133 & 1.326 & .186 & 1.062 & .288 & 1.179 & .239 \\
\hline
\end{tabular}




\section{REFERENCES}

ABS [Australian Bureau of Statistics]. (1998) 1996-97 Small and Medium Enterprises Business Growth and Performance Survey, Australian Bureau of Statistics, Canberra.

ABS [Australian Bureau of Statistics]. (1997) 1995-96 Small and Medium Enterprises Business Growth and Performance Survey, Australian Bureau of Statistics, Canberra.

Appiah-Adu, K. (1997) "Market Orientation and Performance: Do the Findings Established in Large Firms Hold in the Small Business Sector?" Journal of Euromarketing 6(3): 1-26.

Begley, T.M. \& D.P. Boyd. (1986) "Executive and Corporate Correlates of Financial Performance in Smaller Firms" Journal of Small Business Management, 24(2): 8-15.

Berman, J.A., D.D. Gordon, \& G. Sussman. (1997) "A Study to Determine the Benefits Small Business Firms Derive from Sophisticated Planning Versus Less Sophisticated Types of Planning" The Journal of Business and Economic Studies 3(3): 1-11.

Camp, S.M., B. Nenide, R.W. Pricer \& D. Sexton. (1999) "Predicting Financial Performance in Firm Growth: Problems Associated with Recommendations for Using Large Databases", Paper presented at the 1999 Babson College - Kauffman Foundation Entrepreneurship Research Conference, South Carolina.

Chandler, G.N. (1996) "Business Similarity as a Moderator of the Relationship Between PreOwnership Experience and Venture Performance" Entrepreneurship Theory and Practice Spring: 51-65.

Chrisman, J.J.\& J. Leslie. (1989) "Strategic, Administrative, and Operating Problems: The Impact of Outsiders on Small Firm Performance" Entrepreneurship, Theory and Practice 13(3): $37-51$.

Daily, C.M. \& D.R. Dalton. (1992) "Financial Performance of Founder-Managed Versus Professionally Managed Small Corporations" Journal of Small Business Management April: 25-34.

Dyke, L.S., E.M. Fischer \& A.R. Reuber. (1992) "An Inter-Industry Examination of the Impact of Owner Experience on Firm Performance" Journal of Small Business Management 30(4): 72-86.

Gibson, B. (1997) "Reappraising the Link Between 'Best Practice' and Performance in Small Firms: A Research Note" Small Enterprise Research, 5(2): 61-67.

Glen, W. \& J. Weerawardena. (1996) "Strategic Planning Practices in Small Enterprises in Queensland", Small Enterprise Research 4(3): 5-16.

Hornaday, R.W. \& W.J. Wheatley. (1986) "Managerial Characteristics and the Financial Performance of Small Business" Journal of Small Business Management 24(2): 1-7.

ILO [International Labour Organization]. (1998) "Recommendation Concerning General Conditions to Stimulate Job Creation in Small and Medium-Sized Enterprises" 
Recommendation 189 to the General Conference of the International Labour Organization, Geneva, June.

Keasey, K, H. Short \& R. Watson. (1994) "Directors' Ownership and the Performance of Small and Medium Sized Firms in the U.K." Small Business Economics 6: 225-236.

Keats, B.W. \& J.S. Bracker. (1988) "Toward a Theory of Small Firm Performance: A Conceptual Model" American Journal of Small Business 12(4): 41-58.

Kennedy, D., J. Lakonishok \& W.H. Shaw. (1992) "Accommodating Outliers and Nonlinearity in Decision Models" Journal of Accounting, Auditing \& Finance 7(2):161-193.

Kotey, B. \& G.G. Meredith. (1997) "Relationships Among Owner/Manager Personal Values, Business Strategies, and Enterprise Performance" Journal of Small Business Management April: 37-64.

Lumpkin, G.T, \& G.G. Dess. (1996) "Clarifying the Entrepreneurial Orientation Construct and Linking it to Performance" Academy of Management Review 21(1): 135-172.

Lumpkin, G.T, R.C Shrader, \& G.E. Hills. (1998) "Does Formal Business Planning Enhance The Performance of New Ventures?" Paper presented at the 1998 Babson Entrepreneurship Research Conference, Gent, Belgium.

Lyles, M.A., I.S. Baird, J.B. Orris \& D.F. Kuratko. (1993) "Formalized Planning in Small Business: Increasing Strategic Choices" Journal of Small Business Management 31(2): $38-50$.

Matthews, C.H. \& S.G. Scott. (1995) "Uncertainty and Planning in Small and Entrepreneurial Firms: An Empirical Assessment" Journal of Small Business Management 33(4): 34-52.

McKiernan, P. \& C. Morris. (1994) "Strategic Planning and Financial Performance in UK SMEs: Does Formality Matter?" British Journal of Management 5: S31-S41.

McMahon, R.G.P. \& L.G. Davies. (1994) "Financial Reporting and Analysis Practices in Small Enterprises: Their Association with Growth Rate and Financial Performance" Journal of Small Business Management January: 9-16.

Murphy, G.B., J.W. Trailer \& R.C. Hill. (1996) "Measuring Performance in Entrepreneurship Research" Journal of Business Research 36: 15-23.

Olson, P.D. \& D.W. Bokor. (1995) "Strategy Process-Content Interaction: Effects on Growth Performance in Small, Start-Up Firms" Journal of Small Business Management January: $34-44$.

O'Neill, H.M., C.B. Saunders \& A.N. Hoffman. (1987) "Beyond the Entrepreneur: Planning as the Organization Grows" Business Forum 12(4): 38-40.

Pelham, A.M. (1997) "Mediating Influences on the Relationship Between Market Orientation and Profitability in Small Industrial Firms" Journal of Marketing Theory and Practice 5(3): $55-76$. 
Rauch, A. \& M. Frese. (1998) "Planning; Environmental Hostility And Small Business Success: A Contingency Approach On The Relationship Between Planning Of Small Business Owners And Their Success" Paper presented at the 1998 Babson Entrepreneurship Research Conference, Gent, Belgium.

Riggs, W.E. \& J.S. Bracker. (1986) "Operations Management and Financial Performance" American Journal of Small Business 10(3): 17-23.

Risseeuw, P. \& E. Masurel. (1994) "The Role of Planning in Small Firms: Empirical Evidence from a Service Industry" Small Business Economics 6: 313-322.

Robson, G., C. Gallagher \& M. Daly. (1993) "Diversification Strategy and Practice in Small Firms" International Small Business Journal 11(2): 37-53.

Rue, L.W. \& N.A. Ibrahim. (1998) "The Relationship between Planning Sophistication and Performance in Small Businesses" Journal of Small Business Management 36(4): 24-32.

Schwenk, C.R. \& C.B. Shrader. (1993) "Effects of Formal Strategic Planning on Financial Performance in Small Firms: A Meta-Analysis" Entrepreneurship Theory and Practice Spring: 53-64.

Shuman, J.C. \& J.A. Seeger. (1986) "The Theory and Practice of Strategic Management in Smaller Rapid Growth Firms" American Journal of Small Business 11(1): 7-18.

Stone, M.M. \& C.G. Brush. (1996) "Planning in Ambiguous Contexts: The Dilemma of Meeting Needs for Commitment and Demands for Legitimacy" Strategic Management Journal 17: 633-652. 